\title{
Productivity and cost analysis of semi-mechanised and mechanised systems on the Viphya forest plantations in Malawi
}

\author{
${ }^{1,2}$ Elisha Ngulube, ${ }^{1}$ Michal Brink, ${ }^{1}$ Paxie W Chirwa \\ ${ }^{1}$ University of Pretoria, \\ Forest Postgraduate Programme, Plant Sciences Complex \\ Hatfield, Pretoria, South Africa \\ ${ }^{2}$ Mzuzu University, \\ Department of Forestry \\ Mzuzu, Malawi
}

Corresponding author: esn12003@yahoo.co.uk

\begin{abstract}
At least $200000 \mathrm{~m}^{3}$ of timber is harvested annually using semi-mechanised harvesting systems on the Viphya forest plantations in Malawi. Although these systems have long been used on the Viphya, no investigation on their productivity has so far been reported. Additionally, the absence of localised productivity analyses in Malawi has created paucity of information of appropriate timber harvesting systems for production maximisation and cost minimisation. The objective of this study was to compare the production rates and operational costs of chainsaw-grapple skidder (semi-mechanised) and feller buncher-grapple skidder (mechanised) harvesting systems in order to determine the economic feasibility of mechanised systems in the Viphya forest plantations. The study was conducted in Pinus kesiya compartments at Kalungulu and Champhoyo forest stations of the Viphya forest plantations. A work study approach was followed to capture harvesting time and volume data for the semi-mechanised system. Secondary work study data were used to simulate productivity of the mechanised system on similar compartment conditions. A timber
\end{abstract}


harvesting costing model was used to analyse the results. The study showed that the simulated mechanised system was associated with lower operating costs and inventories with higher production rates than the semi-mechanised system. The cost marginal difference was US\$0.89 $\mathrm{m}^{-3}$. It was therefore established that migration to mechanised systems could optimise timber harvesting productivity on the Viphya in future, if optimal volumes are available to ensure the efficient application of the mechanised harvesting system.

Keywords: bunching, chainsaw, feller buncher, extraction, grapple skidder, harvesting system, optimisation, Pinus kesiya, time study.

\section{Introduction}

Raiply (Malawi) Ltd has a timber concession constituting 20000 ha of the 53500 ha of the Viphya forest plantations (GoM 2001). It is estimated that about $200000 \mathrm{~m}^{3}$ of round wood is harvested from the concession area per year using semi-mechanised harvesting systems. The semi-mechanised system is comprised of chainsaws and grapple skidders. Felled trees are extracted to the roadside landing in full-tree form. Full tree harvesting methods could also be accomplished using feller buncher-grapple skidder combinations as basis for mechanised harvesting (Eggers et al. 2010).

The application of mechanised timber harvesting systems is still limited in southern Africa but steadily increasing (Iarocci 2007). As these harvesting systems are not presently available on the Viphya forest plantations in Malawi, there is a need for productivity and operational costs to assess their feasibility on the Viphya. While these systems are typically much safer for the forest workers (Evanson and McConchie 1996), Wang et al. (2004) indicated that high initial costs of mechanised systems become unnecessarily prohibitive for 
small scale harvesting contractors in spite of their well-known high productivity levels in harvesting. Egan and Baumgras (2003) also argue that mechanised systems become less effective where large diameter and irregular terrain exist. The terrain on most of the Viphya is such conducive for the application of mechanised systems except for a small portion that lies in the eastern escarpment of the plantations. On the other hand, manual systems have been criticised as slow and therefore less productive for commercial harvesting on the Viphya (Luhanga 2009). Axes are commonly used for felling and debranching operations largely by small scale contractors in the Viphya plantations. Other productivity studies conducted by Björheden (1998) showed that manual harvesting systems were more favourable for ergonomic, economic and efficiency reasons over mechanised systems in carrying out intermediate (thinning) pine harvests. Manual systems lack bunching capabilities prior to extraction in timber harvesting. Visser and Stampfer (2003) reported significant differences in costs between bunching and non-bunching tasks in pine tree length harvesting system.

This study compared the production rates and operational costs of chainsaw-grapple skidder and feller buncher-grapple skidder harvesting systems in order to determine the economic feasibility of mechanised systems in the Viphya forest plantations. Such information is vital for making blanket recommendations of migration to fully mechanised timber harvesting systems for the plantations in Malawi.

\section{Methodology}

\section{Description of the study site}

The Viphya forest plantations stretch between latitudes $11^{\circ} \mathrm{S}$ and $12^{\circ} \mathrm{S}$ and longitudes $33^{\circ}$ $45^{\prime} \mathrm{E}$ and $34^{\circ} 10^{\prime} \mathrm{E}$ in northern Malawi. The area receives a mean annual rainfall between $750 \mathrm{~mm}$ and $1560 \mathrm{~mm}$ with an overall average of $1200 \mathrm{~mm}^{\text {annum }}{ }^{-1}$. Rainfall is at its peak 
during the summer months of January and March, although showers and mist continue during the dry season, from June to October. The minimum daily temperatures are $10^{\circ} \mathrm{C}$ in winter. Maximum daily temperatures are about $28^{\circ} \mathrm{C}$ in November. The mean annual temperature for the study area is about $19^{\circ} \mathrm{C}$ (VPD 2005). Terrain is undulating with slopes varying from flat to very steep $\left(>19.3^{\circ}\right.$ in eastern escarpments). Soils are reddish in colour with proportions of silt, clay, loam or silt-clay with pronounced quartz material in some ridges. Generally, these soils become highly plastic during the rainy season. In valley bottoms, clayey poorly drained soils are common in the Viphya (Cornelius 1989).

Specific study sites were Pinus kesiya compartments C252B and C253C of Kalungulu forest planted in 1977 and Z151B of Champhoyo forest was planted in 1975 of (Figure 1). The choice of compartments for this study followed a harvesting plan designed by Raiply to undertake clear-felling for its mills. Raiply designates compartments for harvesting based on age, piece size and accessibility. A candidate compartment for harvesting is normally older than twenty-five years with a mean diameter at breast height $(\mathrm{DBH})$ of $>30 \mathrm{~cm}$. Such piece sizes become ideal to provide assortments for a range of log products for the veneer, rough sawn timber and medium density fibreboard mills. Accessibility of the truck transport in the dry or wet seasons is yet another criterion that Raiply uses to select a compartment for harvesting. During the wet season, Raiply opts for ridge roads which are generally accessible or minimises the travel distances off the bitumen Mzuzu-Lilongwe M1 road for the truck transport. $P$. kesiya is regarded as an alternative prime wood after $P$. elliottii (whose stocks have so far dwindled), especially for the plywood production. 


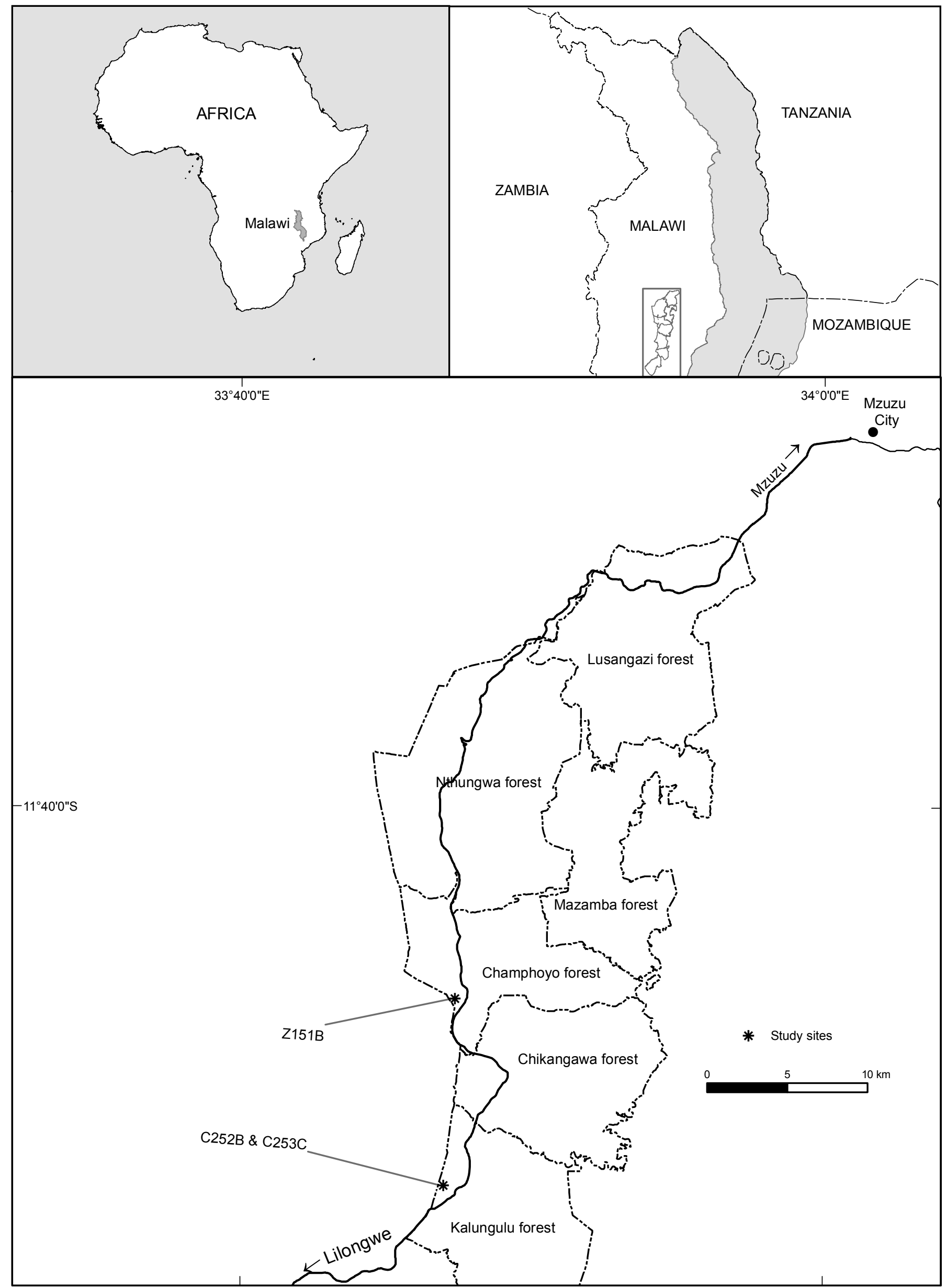

Figure 1. Map of the Viphya forest plantations showing compartments C252B and C253C (Kalungulu) and Z151B (Champhoyo) 


\section{Compartment characteristics}

Pre-harvest stand density of $P$. kesiya at the study sites was estimated to be $375-450$ stems ha'

${ }^{1}$ (SPH) after sanitary thinning activities that were completed in the early 1990's. Kalungulu

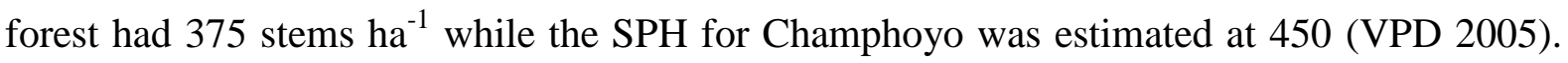
Slopes ranged from $3^{\circ}$ to $14^{\circ}$ in the study sites. The ground conditions were very good, good and moderate as defined by Erasmus (1994) for the terrain classifications for forestry in South Africa. Moderate ground conditions were particularly experienced in compartment Z151B due to incidental winter rains. The maximum ground roughness was "uneven" in all compartments. Table 1 presents the compartment characteristics of the study compartments.

Table 1. Compartment information of the study sites

\begin{tabular}{|c|c|c|c|c|c|c|c|c|}
\hline Compartment & $\begin{array}{l}\text { Total } \\
\text { area } \\
\text { (ha) }\end{array}$ & SPH & $\begin{array}{l}\text { Mean } \\
\text { Dbh } \\
(\mathrm{cm})\end{array}$ & $\begin{array}{l}\text { Mean } \\
\text { Height } \\
\text { (m) }\end{array}$ & $\begin{array}{l}\text { Slope } \\
\left({ }^{o}\right)\end{array}$ & $\begin{array}{l}\text { Ground } \\
\text { condition }\end{array}$ & $\begin{array}{c}\text { Ground } \\
\text { roughness }\end{array}$ & $\begin{array}{c}\text { Brush density } \\
\text { (Visibility) }\end{array}$ \\
\hline C252B & 14.5 & 375 & 41.2 & 27.08 & $5-9$ & Very good & $\begin{array}{l}\text { Slightly } \\
\text { Uneven }\end{array}$ & $>8 \mathrm{~m}$ \\
\hline $\mathrm{C} 253 \mathrm{C}$ & 9.2 & 375 & 41.2 & 27.08 & $3-10$ & Very good & $\begin{array}{l}\text { Smooth to } \\
\text { Uneven }\end{array}$ & $>8 \mathrm{~m}$ \\
\hline Z151B & $70.0^{*}$ & 450 & 38.6 & 29.40 & $9-14$ & $\begin{array}{c}\text { Very good } \\
\text { to } \\
\text { Moderate }\end{array}$ & $\begin{array}{l}\text { Slightly } \\
\text { Uneven to } \\
\text { Uneven }\end{array}$ & $>8 \mathrm{~m}$ \\
\hline
\end{tabular}

* Only about 2 ha were observed for work studies.

\section{Harvesting system description}

The study was carried out on a full-tree timber harvesting system, using a grapple skidder working in combination with either chainsaw felling or a simulated, tracked self-levelling feller buncher (Table 2). Work elements for a chainsaw were sharpening chain, refuel, walk 
to tree, cut and delay. A delay was defined as time $>15$ minutes lost due to personal, technical or operational interruptions (Nurminen et al. 2006).

The choice of a tracked self-levelling feller buncher to undertake simulated mechanised felling was not solely based on compartment characteristics presented in Table 1 but rather on wider range of terrain classes that exist on the Viphya forest plantations. Typical work elements for a feller buncher comprise of move to position, fell (cut), swing tree to bunch, swing to next tree and delays (Thomson 2003, Wang and LeDoux 2003, Acuna et al. 2011).

The operations of a grapple skidder were observed from point of origin (landing), to compartment and back to landing. These operations were sub-divided into the following work elements: drive empty, change position, bunch, drive loaded and drop, turn, align and delay. Critical work elements of primary concern were used in a preliminary study or activity sampling to achieve $95 \%$ confidence level for the minimum required number of cycles in the study. The minimum numbers of cycles for felling and skidding time studies were determined using a statistical method (Kanawaty 1997). Three hundred and forty nine (349) chainsaw felling cycles and 412 skidding cycles were observed during the period of study. Operators were assumed to be average performers for each machine studied. Trees to be skidded were randomly selected by the operator with regard to ease of operation and safety aspects. The operator was assisted in his decision making by the assistant operator in the selection of logs. 
Table 2. Systems design for full-tree harvesting method at Viphya forest plantations

\begin{tabular}{|c|c|c|c|c|c|}
\hline \multirow{2}{*}{\multicolumn{2}{|c|}{ System }} & \multicolumn{3}{|c|}{ Locality } & \multirow{2}{*}{ Operation } \\
\hline & & \multirow[t]{2}{*}{ Compartment } & Skid trail & Roadside landing & \\
\hline 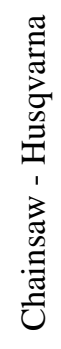 & 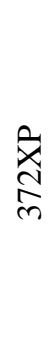 & & & & Motor-manual felling \\
\hline 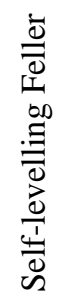 & 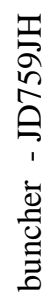 & & & & Mechanised felling and bunching \\
\hline 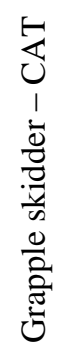 & $\begin{array}{l}\text { v } \\
\text { ñ }\end{array}$ & & & & Extraction \\
\hline
\end{tabular}

\section{Data collection and analysis}

Primary time study elemental time data were measured in centi-minutes using a digital decimal stopwatch. Secondary work study data for the tracked self-levelling fellerbuncher were used (Derek Howe, 2012, John Deere, Nelspruit, South Africa, pers. comm). Total time was calculated as the sum of elemental times constituting a cycle. Delay-free time study data for a chainsaw, grapple skidder and tracked self-levelling feller buncher are presented in Table 3, Table 4 and Table 5 respectively. 
Table 3. Chainsaw's average elemental times and proportions

\begin{tabular}{lcc}
\hline Elements & Average time (min) & Percentage (\%) \\
\hline File & 0.067 & 5 \\
Fuel & 0.095 & 17 \\
Walk to tree & 0.210 & 70 \\
Fell & 0.852 & 100 \\
\hline Total & 1.224 & \\
\hline
\end{tabular}

Table 4. Grapple skidder's average elemental times and proportions

\begin{tabular}{lcc}
\hline Elements & Average time (min) & Percentage (\%) \\
\hline Drive empty & 2.990 & 20 \\
Clear & 0.460 & 3 \\
Change position & 0.590 & 4 \\
Bunch & 5.430 & 36 \\
Drive loaded and drop & 3.988 & 4 \\
Turn & 0.518 & 6 \\
Align & 0.930 & 6 \\
\hline Total & 14.906 & 100 \\
\hline
\end{tabular}

Table 5. Tracked self-levelling feller buncher's average elemental times and proportions

\begin{tabular}{lcc}
\hline Elements & Average time (min) & Percentage (\%) \\
\hline Move to position & 0.180 & 24 \\
Fell & 0.310 & 41 \\
Swing tree to bunch & 0.150 & 20 \\
Swing to next tree & 0.110 & 15 \\
\hline Total & 0.750 & 100 \\
\hline
\end{tabular}

The number of trees felled and extracted to the roadside (landing) per trip was recorded. All incoming full trees per skidding cycle were measured at the landing after debranching and 
cross-cutting operations. Log diameters were measured on the thick-end, middle and thinend in centimetres. Log length was measured in metres using a linear tape. Log volume was estimated using Newton's model (Equation 1) according to Avery and Burkhart (2002).

$V_{u b}=\pi\left(\frac{D_{u b}^{2}+4 d_{m u b}^{2}+d_{u b}^{2}}{240000}\right) L$

Notation:

$$
\begin{array}{ll}
V_{u b} & =\text { volume under-bark in } \mathrm{m}^{3}, \\
\pi & =3.142 \\
D_{u b} & =\text { butt diameter under-bark in } \mathrm{cm}, \\
d_{m u b} & =\text { mid-diameter under-bark in } \mathrm{cm}, \\
d_{u b} & =\text { thin-end diameter under-bark in cm, and } \\
L & =\text { length in } \mathrm{m}
\end{array}
$$

In order to estimate volume under-bark from diameter over-bark, a bark thickness model (Cao and Pepper 1986, Avery and Burkhart 2002) was used. Diameter over-bark and diameter under-bark subsamples were drawn and recorded from the population of $P$. kesiya to enable the development of appropriate bark thickness coefficients (Equation 2).

$D_{u b}=\mathrm{b}_{0}+\mathrm{b}_{1} D_{o b}$

where $b_{0}$ and $b_{1}$ are coefficients of the model, $D_{u b}=$ diameter under-bark in $\mathrm{cm}$, and $\mathrm{D}_{\mathrm{ob}}=$ diameter over-bark in $\mathrm{cm}$.

Extraction distance (compartment to landing) was measured in metres using a GPS. Other site-based information included slope (measured in percentage), ground condition, ground roughness and brush density recorded as categorical data (Erasmus 1994). Soil moisture content (in relative terms) was used to qualify ground conditions; height of obstacle and 
incident of its occurrence were used to qualify ground roughness while visibility distance of the operator was used to define brush density in a compartment. Due to absence of mechanised systems (feller buncher and grapple skidder combinations), synthetic data were adapted for simulation purposes (Forestry Solutions 2007).

Fixed, variable, labour and overhead costs (in US\$ equivalent) of a chainsaw, feller buncher and grapple skidder were recorded for calculation of hourly production costs. Current cost values and exchange rates were applied. A costing model was used to determine the production rates and costs based on average output per machine hour for observed (chainsawgrapple skidder) and simulated (feller buncher-grapple skidder) operations.

\section{Results}

\section{Production rates and costs for semi-mechanised system}

Table 6 shows the production rates and costs of a semi-mechanised harvesting system that had an annual target of $200000 \mathrm{~m}^{3}$ of logs on the Viphya forest plantations. To achieve the target, the system required three chainsaws and six grapple skidders. The production rate for a chainsaw was $71.08 \mathrm{~m}^{3}$ per machine hour $\left(\mathrm{m}^{3} \mathrm{mhr}^{-1}\right)$ at a cost of US\$0.27 $\mathrm{m}^{-3}$. The observed productivity for a grapple skidder averaged $21.51 \mathrm{~m}^{3} \mathrm{mhr}^{-1}$ at a production cost of US $\$ 4.63 \mathrm{~m}^{-3}$. The combined operational cost for the semi-mechanised system was US $\$ 4.90$ $\mathrm{m}^{-3}$. Two people (operator and assistant) were required per machine for any particular production system. 
Table 6. Production rates and costs for a semi-mechanised system

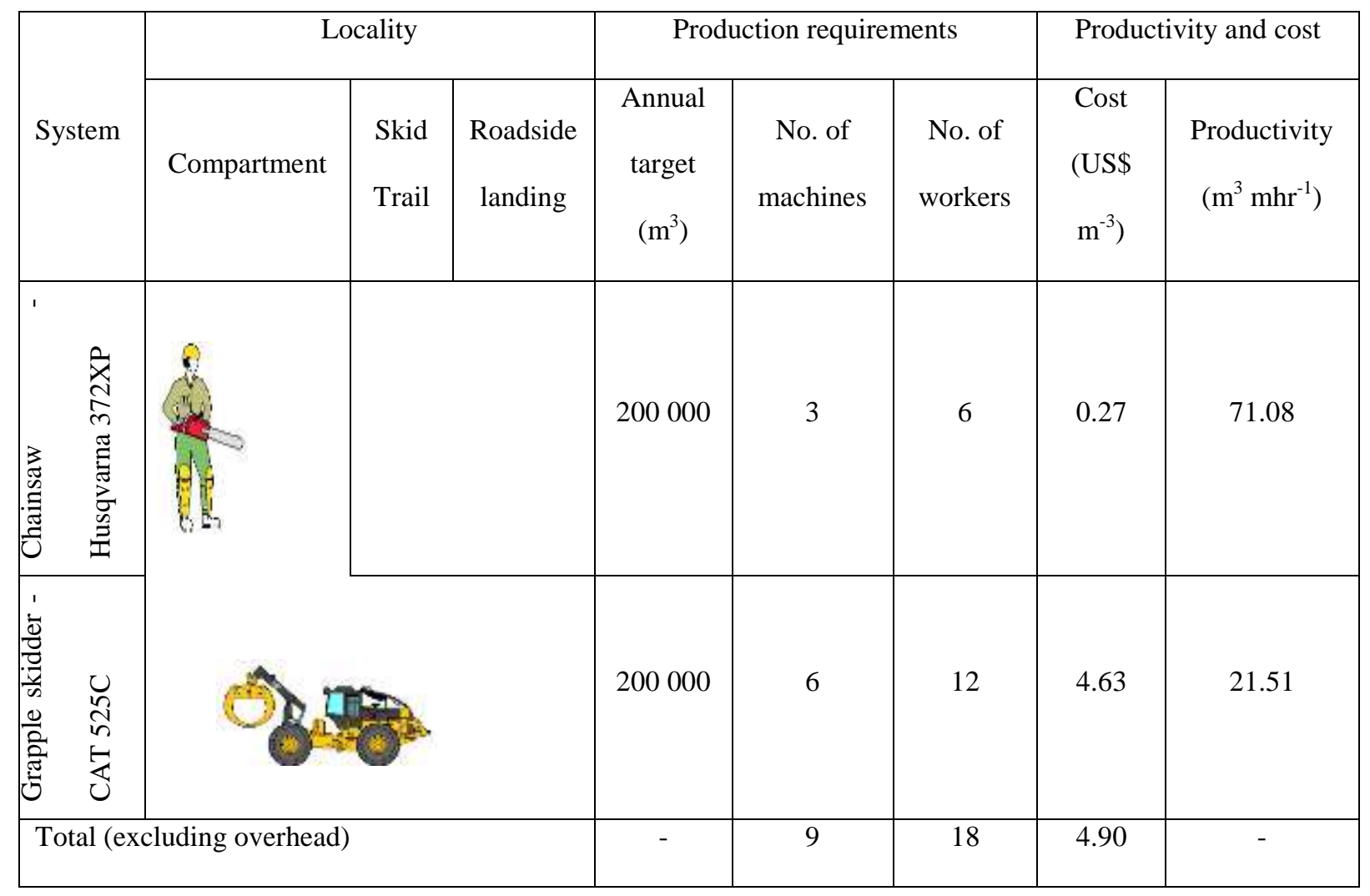

\section{Production rates and costs for mechanised system}

The simulated mechanised system is shown in Table 7. When a feller buncher was used in place of a chainsaw in similar compartment characteristics, two feller bunchers and two grapple skidders were required to produce $200000 \mathrm{~m}^{3}$ annum ${ }^{-1}$. A production cost of US $\$ 2.47 \mathrm{~m}^{-1}$ was associated with a volume production of $116.0 \mathrm{~m}^{3} \mathrm{hr}^{-1}$. The production rate of a grapple skidder was $75.0 \mathrm{~m}^{3} \mathrm{hr}^{-1}$ at a cost of US $\$ 1.54 \mathrm{~m}^{-3}$. The total cost for mechanised system was US $\$ 4.01 \mathrm{~m}^{-3}$ and each machine required one operator. 
Table 7. Simulated production rates and costs for a mechanised system

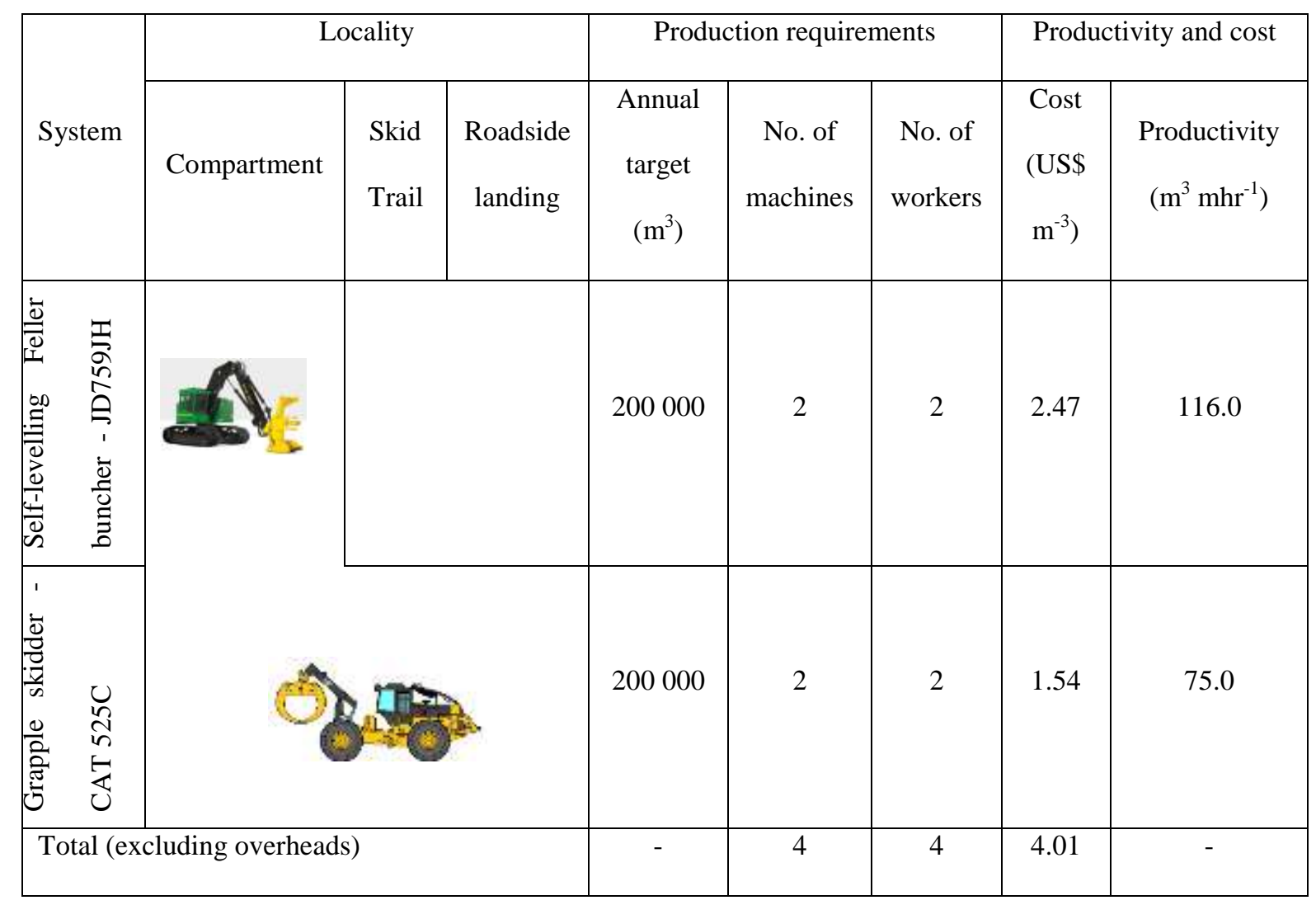

\section{Discussion}

\section{Comparison of systems production rates and costs}

The outputs at the landing imply that the semi-mechanised system (Table 6) was less productive per hour than simulated mechanised system (Table 7). Use of a simulated feller buncher enabled bunching of felled trees prior to extraction with a grapple skidder in a mechanised system, by using the bunching arms fitted to the head. This is an added advantage of mechanised over semi-mechanised systems (Stampfer 1999, Visser and Stampfer, 2003), as the skidder is relieved from fulfilling the bunching activity. Contrary to this, directional felling is significantly less controllable with chainsaw felling, this being further aggravated through trees with excessive lean and felling during windy conditions. No wonder that total felling time took an average of 1.224 minutes in a semi-mechanised system (Table 3). Except for drop in skidder productivity when felling by chainsaw, unplanned trails 
and frequent turns in the compartment by the skidder can lead to adverse environmental problems in ground skidding. The bunching and regulated tree butt presentation (Table 5) minimised total skidding cycle time thereby maximising the associated production rates. Similar reports in favour of mechanised systems exist in timber harvesting literature (Han and Renzie 2005, LeDoux 2010, Acuna et al. 2011).

Although chainsaw operational costs were lower (US\$0.27 $\mathrm{m}^{-3}$ ) in a semi-mechanised system than costs of a feller buncher (US\$2.47 $\mathrm{m}^{-3}$ ) in a mechanised system, bunching offset the total harvesting costs of the systems. The overall operational costs difference between semimechanised (Table 6) and mechanised (Table 7) harvesting system was US\$0.89 $\mathrm{m}^{-3}$. Spinelli and Visser (2009) pointed out that the productivity of the whole system is more important than single machines in an operation. Hence, these findings are similar to arguments also made by Stokes and Hartsough (1993) and, Egan and Baumgras (2003) that the absence of bunching increases the overall costs of timber harvesting.

To achieve optimum productivity, an appropriate harvesting system mix is vital (Uronen 1980). A system mix of three chainsaws to six skidders (Table 6) and two feller bunchers to two skidders (Table 7) was optimal for an annual target of $200000 \mathrm{~m}^{3}$. The number of machines for the semi-mechanised system was higher than those for mechanised system with productivity $\left(\mathrm{m}^{3} \mathrm{mhr}^{-1}\right)$ at the roadside landing being a constraint. Due to lower productivity of grapple skidders in the semi-mechanised system, as a result of load gathering many felled trees were left infield at the end of the day. However, the productivity constraint can be overcome by having a double shift for a grapple skidder to ensure that excess volume felled by two chainsaws is extracted in time. Alternatively, another grapple skidder could be 
purchased, but harvesting contractors tend to resist this option due to high initial capital investment cost associated with grapple skidders in the context of forestry in Malawi.

Furthermore, the annual cut has been balanced by increasing the number of machines in each of the two systems until each system is in a balanced flow. The need for additional chainsaws for debranching and cross-cutting operations of full-trees into logs in both systems at the roadside landing exists. Theoretically, the two systems should thus take the same duration of time. This implies that additional equipment management costs are inevitable particularly in semi-mechanised systems. Although cheaper, mechanised harvesting systems, by their very nature have negative aspects that need to be considered in the context of forest harvesting in Malawi. One key issue that needs to be considered by forest managers relate to the level of after sales service from equipment suppliers, considering the absence of such systems operating in the country at present. This poses a very significant risk of high down time, resulting in excessively expensive harvesting operations over the life of the system.

\section{Conclusions and recommendations}

\section{Conclusions}

From a cost standpoint, mechanised systems appear to be more advantageous than semimechanised systems. The former are associated with lower operating costs and inventories with relatively high production rates. The productivity of a grapple skidder is constrained by the absence of bunching operations in semi-mechanised systems. Bunching and alignment of felled trees minimise turns of grapple skidders while assembling the load or beginning the travel loaded phase of the cycle. Therefore, mechanised systems could help to optimise timber harvesting productivity on the Viphya. 


\section{Recommendations}

Mechanised systems should be tested on the Viphya forest plantations in order to confirm simulated results. A practical application of mechanised systems would be important to validate the associated economic gains due to simulation.

\section{Acknowledgements}

We are grateful to Mzuzu University and the SAFCOL Forest Chair of University of Pretoria for funding this study. Raiply (Malawi) Ltd deserves many thanks for availing their resources for the study. Messrs Khotso Tsotsotso of Barloworld Equipment (Isando) and Derek Howe of John Deere (Nelspruit), we thank you for providing machine cost and technical data. Tsedal Ghebremariam, Marie Smith and Brad Shuttleworth are acknowledged for their analytical support.

\section{References}

Acuna M, Skinnell J, Evanson T, Mitchell R. 2011. Bunching with a Self-levelling Feller buncher on Steep Terrain for Efficient Yarder Extraction. Croatian Journal of Forest Engineering 32: 521531.

Avery TE, Burkhart HE. 2002. Forest Measurements (5th edn). New York: McGraw-Hill.

Björheden R. 1998. Differentiated Processing in Motor Manual and Mechanized Logging. International Journal of Forest Engineering 9: 49-59.

Cao QV, Pepper WD. 1986. Predicting Inside Bark Diameter for Shortleaf, Loblolly and Longleaf Pines. Southern Journal of Applied Forestry 10: 220-224.

Cornelius DW. 1989. The Largest Man-made Forest in Africa. South Viphya Forest Reserve. Mzimba: Viphya Plantations Division.

Egan AF, Baumgras JE. 2003. Ground Skidding and Harvested Stand Attributes in Appalachian Hardwood Stands in West Virginia. Forest Products Journal 53: 59-63. 
Eggers J, McEwan A, Conraide B. 2010. Pinus Saw Timber Tree Optimisation in South Africa: A Comparison of Mechanical Tree Optimisation (Harvester/Processor) versus Current Manual Methods. Southern Forests: A Journal of Forest Science 72: 23-30.

Erasmus D. 1994. National Terrain Classification Systems for Forestry. Bulletin Series 684/3/3. Pietermaritzburg: Institute for Commercial Forestry Research.

Evanson T, McConchie M. 1996. Productivity Measurements of Two Waratah 234 Hydraulic Tree Harvesters in Radiata Pine in New Zealand. International Journal of Forest Engineering 7: 4152.

Forestry Solutions. 2007. BOP Forestry: Harvesting. Available at: www.forestrysolutions.net [accessed on 26 April 2012].

Government of Malawi (GoM). 2001. Malawi's National Forestry Programme: Priorities for Improving Forestry and Livelihoods. Lilongwe: Department of Forestry, NFP Co-ordination Unit.

Han H, Renzie C. 2005. Effect of Ground Slope, Stump Diameter, and Species on Stump Height for Feller bunchers and Chainsaw Felling. International Journal of Forest Engineering 16: 81-88.

Iarocci P. 2007. Mechanisation in South Africa. Official Publication of Tigercat Industries Inc. Between the Branches, 17 July 2007, Ontario.

Kanawaty G. (ed.) 1997. Introduction to Work Study (4th [revised] edn). Johannesburg: Skotaville Publishers.

LeDoux CB. 2010. Mechanised Systems for Harvesting Eastern Hardwoods. General Technical Report NRS-69. Broomall: United States Department of Agriculture.

Luhanga J. 2009. The Timber Trade in Malawi. Resource Insight No. 7. Johannesburg: Southern Africa Resource Watch.

Nurminen T, Korpunen H, Uusitalo J. 2006. Time Consumption Analysis of the Mechanised Cut-toLength Harvesting System. Silva Fennica 40: 335-363.

Spinelli R, Visser RJM. 2009. Analysing and Estimating Delays in Wood Chipping Operations. Biomass and Bioenergy 33: 429-433. 
Stampfer K. 1999. Influence of Terrain Conditions and Thinning Regimes on Productivity of a Track-Based Steep Slope Harvester. In: Proceedings of the International Mountain Logging and $10^{\text {th }}$ Pacific Northwest Skyline Symposium, March 28- April 1, 1999, Corvallis, Oregon. pp $78-87$.

Stokes BJ, Hartsough BR. 1993. Development and Analysis of SRIC Harvesting Systems. In: First Biomass Conference of the Americas Proceedings: Energy, environment, agriculture, and industry, 30 August-2 September, Burlington. pp 302-308. Available at: http://www.treesearch.fs.fed.us/pubs/7367 [accessed on 14 June 2012].

Thomson JD. 2003. Productivity of a Tree Length Harvesting System Thinning Ponderosa Pine in Northern Arizona. In: Council on Forest Engineering Conference Proceedings of September 7-10, 2003: Forest Operations Among Competing Forest Uses, Bar Harbor.

Uronen P. 1980. Systems Analysis in Forest and Forest Industry: An Overview. Laxenberg: International Institute for Applied Systems Analysis.

Viphya Plantations Division (VPD). 2005. Annual Report: 2004-2005. Mzimba: Viphya Plantations Division.

Visser R, Stampfer K. 2003. Tree-Length System Evaluation of Second Thinning in a Loblolly Pine Plantation. Southern Journal of Applied Forestry 27: 77-82.

Wang J, LeDoux CB. 2003. Estimating and Validating Ground-Based Timber Harvesting Production through Computer Simulation. Forest Science 49: 64-76.

Wang J, Long C, McNeel J, Baumgras J. 2004. Productivity and Cost of Manual Felling and Cable Skidding in Central Appalachian Hardwood Forests. Forest Products Journal 54: 45-51. 